\title{
"A Gem among the Rocks"-Identifying and Measuring Visual Preferences for Mountain Lakes
}

\author{
Uta Schirpke ${ }^{1,2, *(\mathbb{D})}$, Rocco Scolozzi ${ }^{3,4}$ (D) and Ulrike Tappeiner ${ }^{1,2} \mathbb{D}$ \\ 1 Institute for Alpine Environment, Eurac Research, Viale Druso 1, 39100 Bozen/Bolzano, Italy; \\ Ulrike.Tappeiner@uibk.ac.at \\ 2 Department of Ecology, University of Innsbruck, Sternwartestrasse 15, 6020 Innsbruck, Austria \\ 3 Department of Sociology and Social Research, University of Trento, Via Verdi 26, 38122 Trento, Italy; \\ rocco.scolozzi@unitn.it \\ 4 -skopìa s.r.l. Anticipation Services ${ }^{\circledR}$, via Salita dei Molini 3, 38123 Trento, Italy \\ * Correspondence: uta.schirpke@eurac.edu
}

check for updates

Citation: Schirpke, U.; Scolozzi, R.; Tappeiner, U. “A Gem among the Rocks"-Identifying and Measuring Visual Preferences for Mountain Lakes. Water 2021, 13, 1151. https://doi.org/10.3390/w13091151

Academic Editor: Athanasios Loukas

Received: 29 March 2021

Accepted: 20 April 2021

Published: 22 April 2021

Publisher's Note: MDPI stays neutral with regard to jurisdictional claims in published maps and institutional affiliations.

Copyright: (C) 2021 by the authors Licensee MDPI, Basel, Switzerland. This article is an open access article distributed under the terms and conditions of the Creative Commons Attribution (CC BY) license (https:// creativecommons.org/licenses/by/ $4.0 /)$.

\begin{abstract}
The high visual quality of lakes bolsters aesthetic and recreational experiences, but little is known about the specific visual preferences related to mountain lakes. This study therefore aimed at assessing people's preferences on visual characteristics of mountain lakes using an online questionnaire. Adopting a qualitative approach, we first identified major recognised characteristics of mountain lakes, i.e., respondents indicated that mountain lakes are typically small-sized lakes with clear, cold and blue water and are embedded in a natural mountain landscape. Then, we used different picture sets related to water clarity, water colour, presence of algae, lake shore and surrounding land cover to quantify preferences. Our results indicated a clear preference for blue, clear water and the absence of algae as well as large rocks at the lake shore and forest around the lake. In particular, preferences related to visual water characteristics were highly homogeneous across socio-cultural groups and confirmed previous findings. To illustrate the applicability of our findings, we integrated our results with spatial and limnological data to quantify aesthetic values for four selected study lakes in the European Alps. Finally, we discuss our findings in the context of increasing demand for nature-based experiences and the implications for decision-making.
\end{abstract}

Keywords: aesthetic value; photo-based questionnaire; water clarity; preferences; European Alps

\section{Introduction}

European mountain landscapes are rich in small natural lakes, which are highly appreciated for recreational purposes [1]. The quality of aesthetic experiences and recreational activities such as swimming or nature observation, however, greatly depends on the visual appearance of the water [2-4]. Water clarity seems to be the most perceived aspect and has been positively related to perceived benefits from viewing or swimming [2,5]. High water clarity is also closely linked to water colours of the green-blue spectrum and the absence of aquatic vegetation [3,6-9] and a high perceived visual quality is often interpreted as good ecological water quality [10]. Accordingly, clearer lakes were found to have higher visitation rates compared to those of lower levels of water clarity [11]. Moreover, the appearance of the lake shore and the surrounding landscape affects aesthetic experiences [12-14], while easy access to the water is important for aquatic sports or recreational activities at the lake shore [15].

Compared to large and low altitude lakes, mountain lakes are less exploited for uses such as water provision, fish production, hydropower generation or aquatic recreation due to their usually small size and remoteness, but they are still largely exposed to environmental and anthropogenic pressures affecting the physical, chemical and biological characteristics of lakes [16,17]. For example, increasing eutrophication may originate from atmospheric nutrient inputs [18], fish feeding related to recreational angling [19], waterbased activities such as boating, swimming and diving [20] or hiking activities in proximity 
to lakes [21]. Consequently, changes in ecosystem health and water quality can lead to a decline in associated ecosystem services and benefits for human well-being $[17,22]$.

In the light of the above-mentioned pressures, mountain lakes need to be carefully managed, taking into account the increasing demand for nature-based experiences [23]. However, studies related to aesthetic preferences of mountain lakes are still lacking. Therefore, we assessed people's preferences on the visual characteristics of mountain lakes using a photo-based online questionnaire. Specifically, we address the following questions:

1. What are typically recognised characteristics of mountain lakes?

2. What are aesthetic preferences related to water clarity and colour, the presence of algae, the composition of the lake shore and surrounding land cover and, are these influenced by the socio-cultural background of the respondents?

3. How can the collected information be used for assessing the aesthetic value of mountain lakes?

Below, we first present the questionnaire design and provide details on data collection and analysis. We also exemplify the quantification of the results for four selected study lakes in the European Alps and discuss our findings in the light of the increasing demand for nature-based experiences.

\section{Materials and Methods}

\subsection{Questionnaire and Data Collection}

Based on the findings of previous studies $[2,3,13]$, we hypothesise that water clarity and colour, the presence of algae, the composition of the lake shore and the surrounding land cover influence aesthetic preferences of mountain lakes. We therefore used a photobased questionnaire containing six different picture sets (see Section 3.3) related to (1) water clarity, (2) water colour, (3) presence of algae, (4) lake shore at lower altitudes, (5) lake shore at higher altitudes, and (6) surrounding land cover. Picture set 1 included two pictures to compare preferences between clear and turbid water. Picture set 2 comprised four pictures showing different colours of lake water, ranging from deep blue to a greyish colour. Three pictures were used to evaluate the absence/increasing level of the presence of algae. Picture sets 4 and 5 each included four pictures representing details of different types of lake shore, mostly related to lower altitudes and higher altitudes, respectively. The four pictures of picture set 6 showed a larger view of predominating land cover types around mountain lakes.

To prepare the questionnaire, we first selected suitable photographs from different lakes across the European Alps. All pictures were taken during the summer season (JuneSeptember) to depict similar conditions (e.g., no snow/ice, similar phenological stage of the surroundings). The original pictures were cropped to focus on the different aspects, paying attention to maintain a similar level of detail and the same picture size. For picture sets 1 to 3, we also made sure that they showed only the lake water without greater detail of the lake shore. For the sets 4 to 6, we paid attention that these had similar portions of water as well as approximately the same water characteristics (colour, surface) to reduce the influence of the lake water on the respondent's choice. If possible, we included pictures with similar weather and sunlight conditions in each picture set.

The six picture sets were arranged in an online questionnaire using Google Forms (https:/ / docs.google.com/forms/ (accessed on 8 April 2021)). After a short introduction including a definition on mountain lakes as being "smaller-sized natural lakes, which are located at least 1000 meters above sea level", we first asked the respondents in an open-ended question to indicate typical characteristics of mountain lakes ("During an excursion you pass by a natural mountain lake. What best defines the characteristics of this lake? Please briefly describe these in a few words."). In the following, each picture set was shown, asking the participants to indicate which image they preferred. Pictures of each set were each time randomly sorted to avoid primacy bias [24]. Finally, we asked the respondents to provide information regarding gender, age, cultural background, relation to the Alps, nature connectedness and lake affinity. 
A first version of the questionnaire was filled out by 17 respondents in a pre-test. Based on their comments, several explanations were refined to avoid misunderstanding. The final questionnaire was translated into three languages (English, German and Italian) and data were collected via an online survey between July and December 2020. The links to the questionnaires were distributed via social media channels, newsletters and by sending invitations via email, targeting people with an interest in mountain lakes such as members of Alpine clubs of different countries (Austria, Germany and Italy) or associations of biologists, limnologists, etc. Participation was anonymous and on a voluntary basis. All participants confirmed their voluntary participation before initiating the questionnaire. Moreover, participants were informed that they could withdraw at any time and that all data would be treated confidentially and not be passed on to third parties. To secure privacy, no IP addresses or other identifiers/codes were collected. The indication of socio-cultural information was not required to complete the questionnaire. All completed questionnaires were recorded in a database.

\subsection{Data Analysis}

Lake characteristics were identified from the open-ended question adopting a qualitative analysis of free lists [25]. All German and Italian responses were translated into English, progressively merging conceptually and semantically similar terms (e.g., clarity of water-clear water), which resulted in 151 different terms. These terms were aggregated into 11 groups and four categories describing various aspects in relation to water, lake, experience and location by one individual and then discussed with the other authors. We calculated the frequencies of the terms, groups and categories. We also classified the terms depending on whether they indicated general attributes (e.g., water colour) or specified the attributes (e.g., blue colour). Specific terms with at least three mentions were then visualized in a word cloud, using an online word cloud creator (https://wordart.com/ (accessed on 8 April 2021)).

All image sets were analysed separately. After recoding the responses into absence/presence, we calculated the mean preference scores and identified significant differences among the image preferences, applying paired t-tests in SPSS software package (version 26, IBM, Armonk, NY, USA). Moreover, we analysed differences across sociocultural groups using the Chi-squared test.

\subsection{Case Study Application}

\subsubsection{Study Lakes}

To exemplify the applicability of the gathered information on visual lake characteristics, we selected four mountain lakes located in the Autonomous Province of South Tyrol in Italy (Figure 1, Table 1). South Tyrol is situated in the Central European Alps and is rich in small lakes. Tourism is of economic importance (about $11 \%$ of the added value) and about 7.5 million tourists visit South Tyrol per year, mainly coming from Germany and other Italian regions [26].

\subsubsection{Indicators for Aesthetic Value}

To measure the overall aesthetic value of mountain lakes, we calculated five indicators (Table 2) integrating the results of the survey with spatial and limnological data. Since limnological variables such as Secchi depth and chlorophyll-a represent water clarity well $[2,3,8]$, we calculated two distinct indicators for all study lakes based on data measured in the project CLAIMES by Kurmayer et al. (unpublished data; for project details, see https:/ / www.uibk.ac.at/projects/claimes/ (accessed on 8 April 2021)). Spatial data on littoral habitat types as well as the land cover types near the lake ( up to $50 \mathrm{~m}$ ) were digitized from orthophotos with a spatial resolution of $0.5 \times 0.5 \mathrm{~m}$, provided by the Autonomous Province of South Tyrol. The resulting maps were integrated with information from photographs for details, distinguishing the four littoral types and four land cover types as used in the questionnaire. All indicators were rescaled to values between 0 and 
1 using maximum value transformation. Finally, we summed up all rescaled indicator values for each lake, giving each indicator the same importance and accounting for positive or negative valuation.

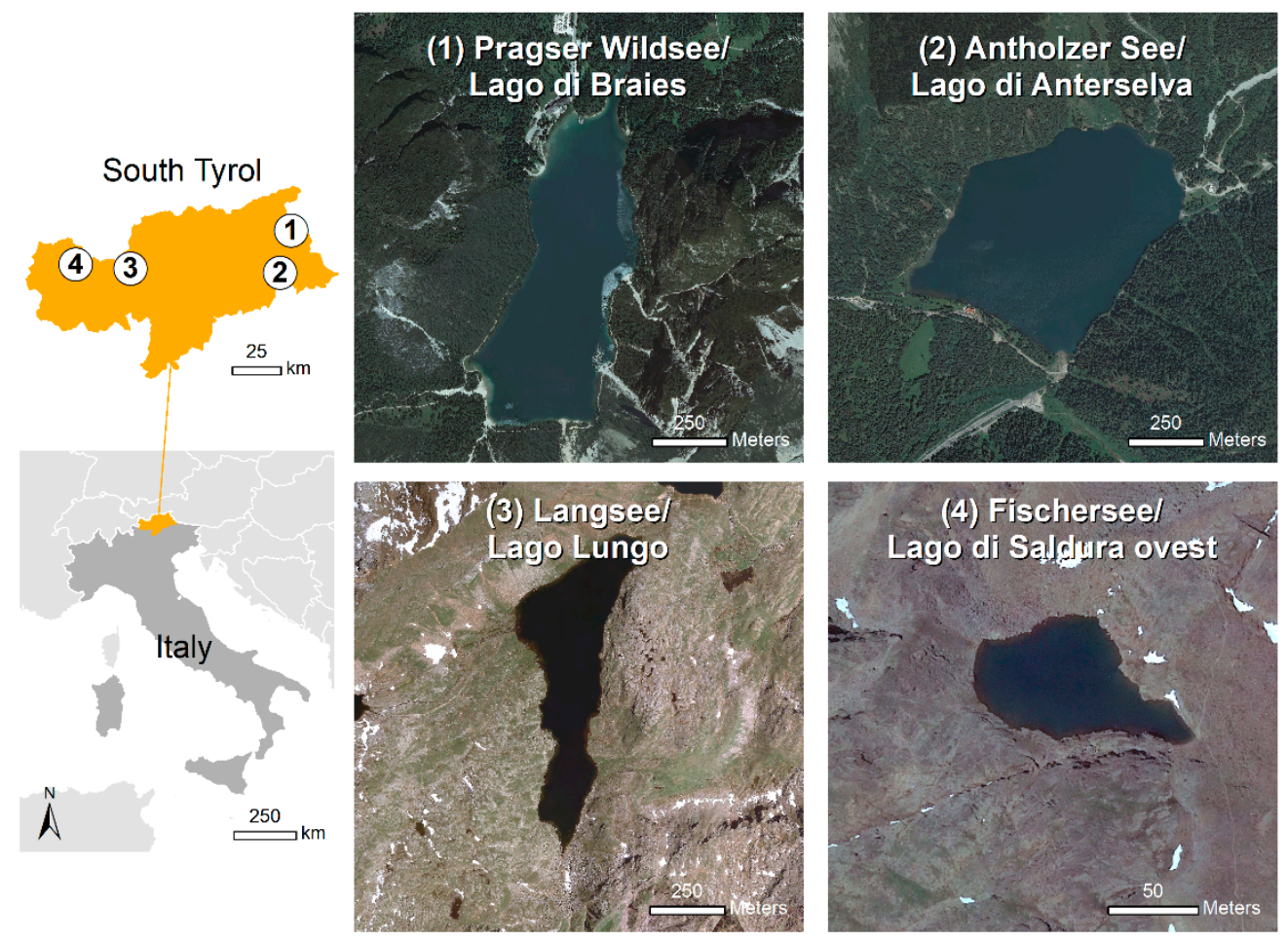

Figure 1. Study lakes located in South Tyrol (Italy). Data source: orthophotos from the Autonomous Province of South Tyrol (2011).

Table 1. Characteristics of the study lakes.

\begin{tabular}{|c|c|c|c|c|}
\hline Lake Characteristics & $\begin{array}{c}\text { Antholzer See (Lago } \\
\text { di Anterselva) }\end{array}$ & $\begin{array}{c}\text { Pragser Wildsee (Lago } \\
\text { di Braies) }\end{array}$ & Langsee (Lago Lungo) & $\begin{array}{l}\text { Fischersee (Lago di } \\
\text { Saldura ovest) }\end{array}$ \\
\hline Area (ha) & 43.24 & 35.82 & 19.59 & 0.54 \\
\hline Elevation (m a.s.l.) & 1642 & 1493 & 2381 & 2758 \\
\hline Volume $\left(10^{6} \mathrm{~m}^{3}\right)$ & 11.04 & 5.30 & 2.58 & 0.03 \\
\hline Area watershed (ha) & 1887.15 & 2930.55 & 199.45 & 3.08 \\
\hline Main land cover types & Forest & Forest & Grassland, rocks & Rocks \\
\hline $\begin{array}{l}\text { Walking time from } \\
\text { nearest parking or } \\
\text { cable car station }(\mathrm{h})\end{array}$ & 0.05 & 0.05 & 3.50 & 2.50 \\
\hline
\end{tabular}

Table 2. Indicators for quantifying the aesthetic value of mountain lakes.

\begin{tabular}{|c|c|c|}
\hline Indicator & Valuation & Method \\
\hline Water colour & Positive & $\begin{array}{c}\text { Preference score from survey (picture set } 1 \text { ) estimated from photographs } \\
\text { and field survey }\end{array}$ \\
\hline Water clarity & Positive & Secchi depth (m) obtained from CLAIMES (unpublished data) \\
\hline Presence of algae & Negative & Chlorophyll-a ( $\left.\mu \mathrm{g} \mathrm{L}^{-1}\right)$ obtained from CLAIMES (unpublished data) \\
\hline Littoral preference & Positive & $\begin{array}{l}\text { Preference score from survey weighted by the length of each littoral habitat } \\
\text { type (picture set } 5 \text { ) }\end{array}$ \\
\hline Land cover preference & Positive & $\begin{array}{c}\text { Preference score from survey weighted by the length of each land cover } \\
\text { type (picture set } 6 \text { ) }\end{array}$ \\
\hline
\end{tabular}




\section{Results}

\subsection{Characteristics of Respondents}

From the online survey, we received 526 valid responses. Female respondents prevailed over male respondents, while age groups over and above 40 years were balanced (Table 3). A higher proportion of the respondents were German speaking. More respondents visited the Alps for touristic purposes compared to those who live and grew up in the Alps. Most respondents indicated a good connectedness to nature and about half of all respondents had a high lake affinity.

Table 3. Socio-cultural characteristics of respondents.

\begin{tabular}{ccc}
\hline Socio-Cultural Variables & Classification & Sample Proportion (\%) \\
\hline Gender & female & 61.5 \\
& male & 38.5 \\
Age & $16-39$ years & 49.7 \\
& $40+$ years & 50.3 \\
Cultural background & German-speaking & 55.9 \\
& Italian-speaking & 39.9 \\
Relation to Alps & English * & 4.2 \\
& Low (visits the Alps primarily as a tourist) & 43.7 \\
Nature connectedness & Strong (lives and grew up in the Alps) & 38.0 \\
& Low (spending time in nature less than several times a month) & 18.3 \\
Lake affinity & High (spending time in nature at least several times a week) & 35.8 \\
& Low (<3 visits to lakes a year) & 64.2 \\
\end{tabular}

${ }^{*}$ Class not included for testing differences across socio-cultural groups.

\subsection{Characteristics of Mountain Lakes Mentioned by the Respondents}

Respondents mentioned various characteristics related to the water (e.g., quality, temperature, and colour), the lake (e.g., shape and shore), the location, as well as terms related to subjective experiences and feelings (Figure 2, Table A1). Summarizing the characteristics recognised by the respondents, mountain lakes are of smaller size with a natural shore, embedded in a natural mountain landscape, and the water is typically clear, cold, blue, clean, and calm. With regard to experiences, respondents mostly mentioned the beauty, tranquillity and silence of the lakes.

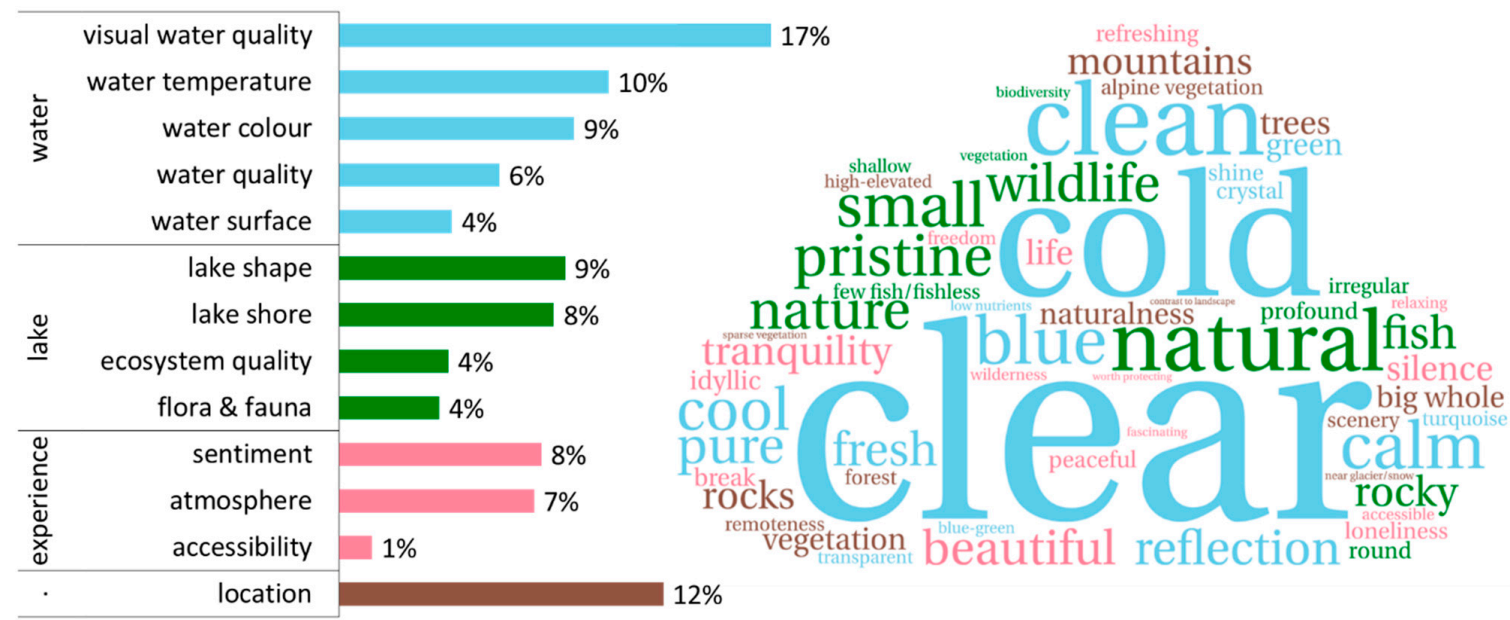

Figure 2. Frequency of terms in each group (left) belonging to the four categories water, lake, experience and location and word cloud (right) of the most mentioned terms ( $>3$ mentions) characterizing mountain lakes. The word cloud was created using https:/ / wordart.com/ (accessed on 8 April 2021). 


\subsection{Preferences Related to Visual Characteristics}

The obtained preference scores from the responses showed in most cases a clear preference for one image (Figure 3). With regard to visual water characteristics, statistically significant preferences were obtained for clear water (1a) and the complete absence of algae (3a), while dark and medium blue colours ( $2 \mathrm{a}$ and $2 \mathrm{~b}$ ) were preferred over light blue (2d) and greyish colours (2c). Preferences related to the lake shore were less pronounced in image set 4 . Respondents slightly preferred shrubs (4b) over grass with rocks (4d), both significantly differing from the other two images (4a and 4c), while there was a clear and statistically significant preference for large rocks (5a). In terms of surrounding land cover, there was a clear preference for forest (6d), followed by grassland (6c) and screes (6b).

(1) Water clarity
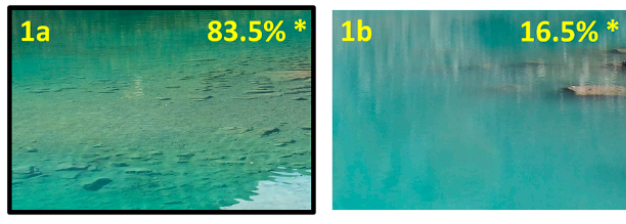

(2) Water colour
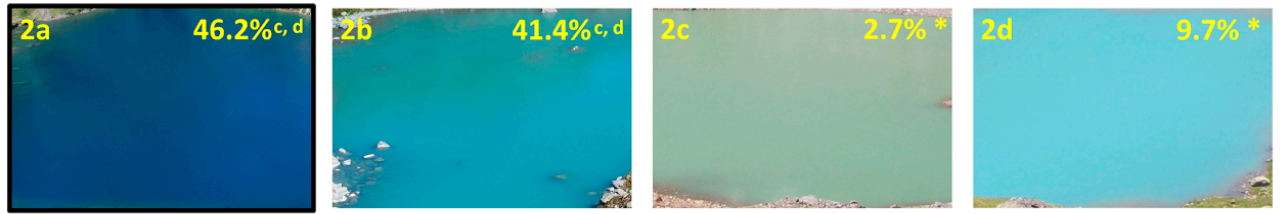

(3) Presence of algae
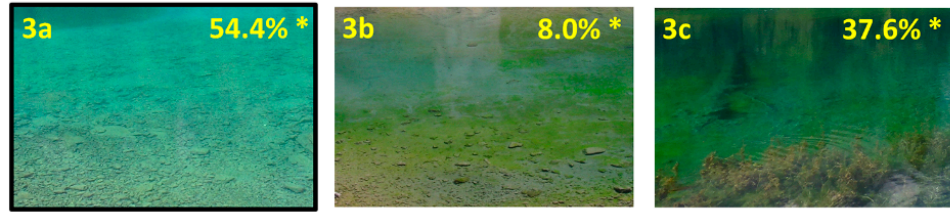

(4) Lake shore
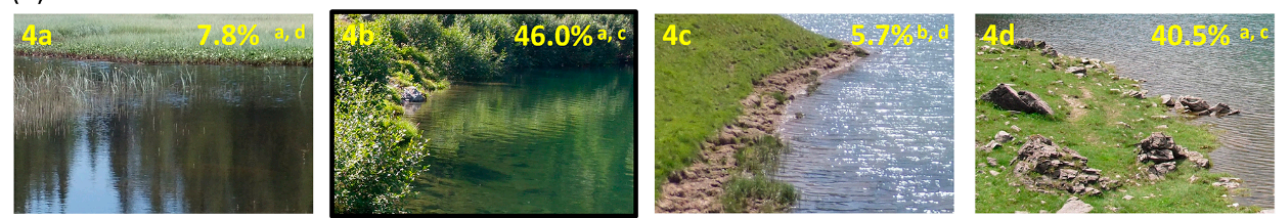

(5) Lake shore
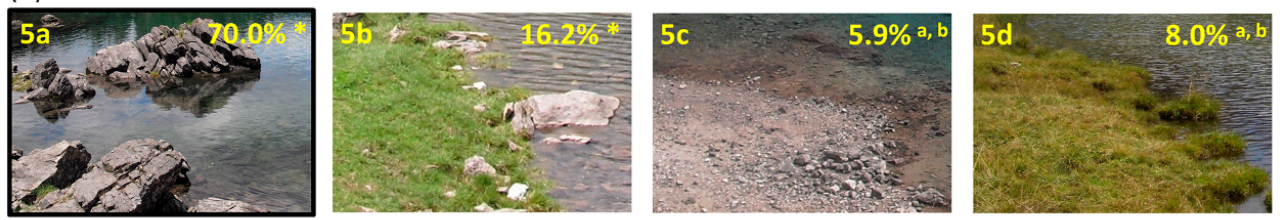

(6) Surrounding land cover
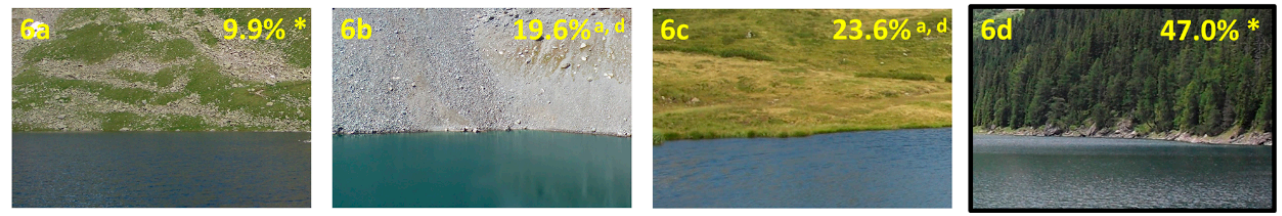

Figure 3. Preferences (\%) related to visual characteristics of lake water (1-3), lake shore $(4,5)$ and surrounding land cover (6). The most preferred image is indicated by a black frame. The asterisk indicates a statistically significant difference in overall preference from other images, while the letters $(\mathrm{a}, \mathrm{b}, \mathrm{c}, \mathrm{d})$ specify significant differences in relation to individual pictures ( $t$-test, $p<0.01)$. Images by U. Schirpke. 
Some differences across socio-cultural groups were found, although not significantly changing the order of preference within each image set (Table A2). Most differences occurred for age related to the lake shore. While people $<40$ year indicated more often $4 \mathrm{~b}$ and $5 \mathrm{a}$, images $4 \mathrm{a} / 4 \mathrm{c}$ and $5 \mathrm{~b}$ were selected more often by people $40+$. Italian-speaking people had a higher preference for image 5 a compared to German-speaking respondents. Tourists and people with low lake affinity indicated more often forest (6d), while a higher share of residents and people with high lake affinity and selected image $6 a$.

\subsection{Aesthetic Value of Study Lakes}

The overall aesthetic value based on five indicators varied across the four study lakes (Figure 4). Highest in aesthetic value was Pragser Wildsee, mostly due to high land cover preference and high water clarity, followed by Antholzer See, which had very high water clarity and low presence of algae but less preferred littoral habitats. Fischersee had lower values due to lower water clarity and low land cover preference, while Langsee had the lowest aesthetic value due to highest presence of algae and lowest land cover preference.

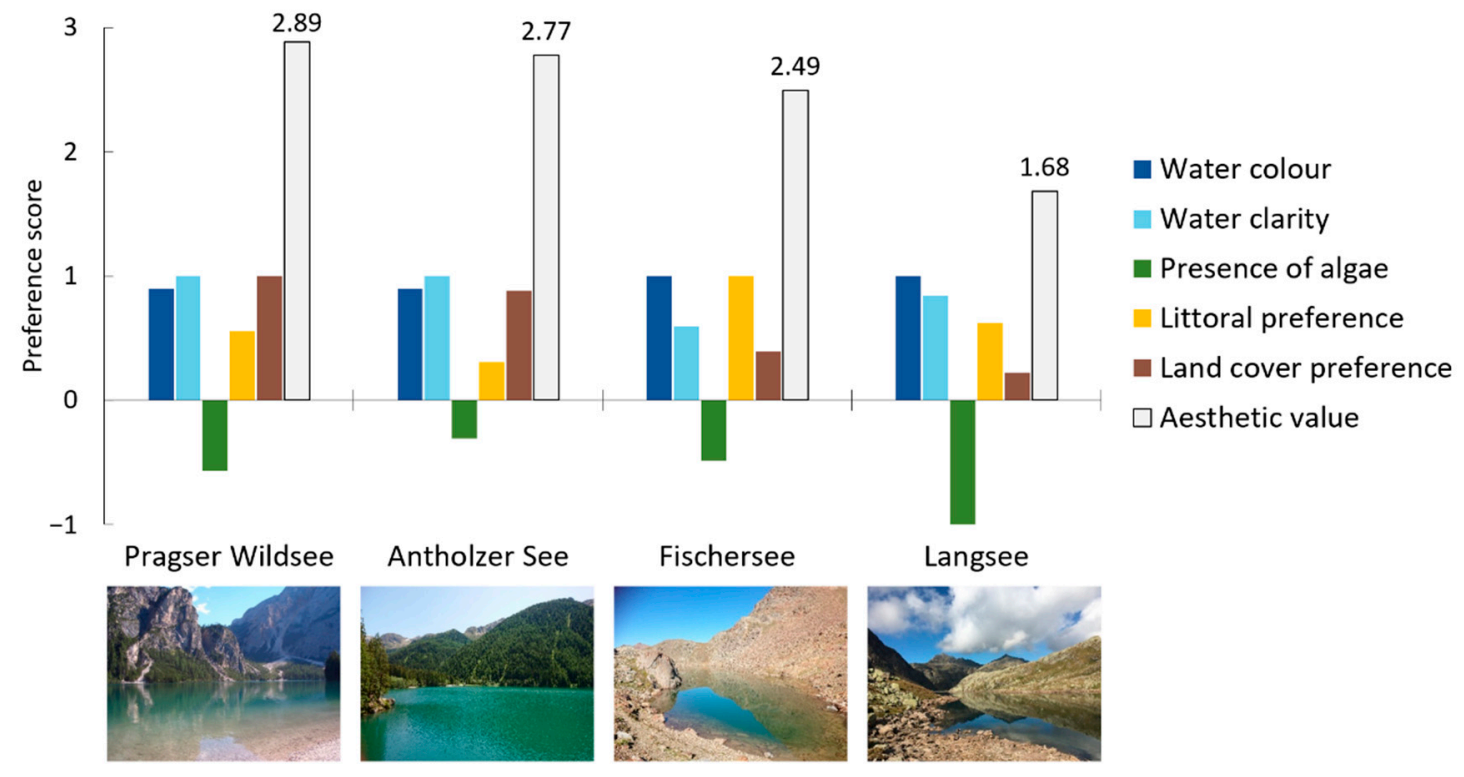

Figure 4. Standardised scores of five indicators used to derive the overall aesthetic value of four study lakes. Photographs by M. Ebner and U. Schirpke.

\section{Discussion}

\subsection{Characteristics and Preferences of Mountain Lakes}

In this study, we collected terms that allowed us to identify major characteristics of mountain lakes, i.e., small-sized lakes with clear, cold and blue water that are embedded in a natural mountain landscape. Similar to other studies $[25,27]$, the terms mentioned by the respondents referred mostly to biophysical features of the lakes and surrounding landscapes, but also included experiences, activities and feelings associated to mountain lakes, although respondents were not asked to indicate such aspects. The use of such terms is very useful in the explanation of human-nature relationships and can be associated to cultural ecosystem services such as aesthetic and recreational values or sense of place $[1,25]$. Our results indicate, for example, that mountain lakes are highly appreciated for their beauty, the tranquillity and pristine environment, and that people associate various positive feelings (e.g., breath-taking, fascinating, and impressive) with the lakes. Regarding the biophysical characteristics, the most frequently mentioned terms referred to visual characteristics of the lake water as well as to the lake shore and landscape in which the lakes are embedded. This supports our underlying hypothesis for selecting the picture sets and can be explained by a holistic perception of landscapes [28]. Moreover, respondents 
mentioned terms relating to the quality of the environment by indicating naturalness (i.e., the absence of constructions) in reference to the lake shore as well as the surrounding landscape. However, a shortcoming of using such open-ended questions in an online-survey in comparison to interviews in situ is that we could not ask participants to provide more details or to be more specific in their answer. About $13 \%$ of the mentioned terms only indicated general categories such as "water colour" or "shape" without specifying whether they intended blue or green water colour or the small, large, round or irregular shape of the lake.

With regard to the photo-based questions, our results related to water colour and clarity as well as the presence of algae greatly match those of other studies $[2,3,8,11]$. Visual preference for blue colours may have an evolutionary origin [29], but it can also be explained by the positive associations with water quality (clean water and health) [9]. In contrast to other studies [3,7], the picture with the highest amount of algae was preferred over the picture with a lower percentage, but we suspect that the respondents may have been influenced in their choice by the water colour.

This study is novel in focusing on the visual preferences of the shore of natural mountain lakes, while other studies discussed issues related to human-made features or accessibility for large and low-elevated lakes $[13,14]$. In both picture sets, preferences seem to be influenced by the naturalness of the lake shore, e.g., grassland with signs of use (picture 4b) was least selected, while the amount of vegetation cover is not linked to the preferences (picture set 5). In contrast to our expectations and studies on preferences for mountain landscapes [30], forest (picture 6d) in the lake surroundings was preferred over open land cover types that are typical for high elevations. A possible explanation could be that the image detail is slightly different in the case of forest, allowing a greater view at the landscape [31] or that people associate higher naturalness with forested landscapes [32]. In general, the preferences across socio-cultural groups were highly homogeneous, in particular with regard to the water characteristics, as also found in other studies [2,3]. Nevertheless, we found few differences in preferences related to the lake shore and surrounding land cover across socio-cultural groups, mostly related to age and lake affinity, which is similar to Cai and Boromisza [13].

\subsection{Applicability and Future Perspectives}

By combining our results from the photo-based questions with limnological and spatial data, this study illustrates their applicability for estimating the aesthetic value of mountain lakes in a simple but holistic way. The same approach can be used for other mountain lakes in similar socio-ecological context, but it may be necessary to collect preferences of the lake shore and the surrounding landscape if lakes are located in other landscapes. Preferences for the lake shore may also be different for low-elevated lakes that are predominantly used for recreational fishing or aquatic activities such as swimming, and boating, where accessibility to the water or suitability of the lake shore to carry out recreational activities may influence preferences, at least for specific user groups. Moreover, the results could be further improved by integrating preferences of the surrounding landscape [30], as respondents mentioned the importance of the mountain landscape in which the lakes are embedded. This is also important for the approval of new constructions, as respondents indicated the importance of natural environments without anthropogenic influence. However, impacts on visual quality are currently disregarded in decisions about new hydropower plants [33].

Other characteristics, which were mentioned by the respondents and also indicated in user-generated tags of social media data [1], such as reflections of the surrounding landscape/blue sky in the lake may be more difficult to consider. Further research aiming at quantifying and modelling aesthetic values of mountain lakes should therefore evaluate the influence of the landscape on aesthetic lake preferences. Future steps also need to include a validation of the modelling results of the overall aesthetic value of each lake (Figure 4). In a simple way, this could be performed by carrying out a standardised photo- 
based survey, asking participants to rate pictures of the four study lakes according to their appraisal. By eliciting the motivation for their choice, a deeper understanding of aesthetic preferences could be obtained [34]. A more demanding way in terms of human and financial resources would be to carry out in situ semi-structured interviews, using the study lakes as direct stimuli instead of presenting them on photographs. As the respondents are directly involved in the landscape to be evaluated, this allows for more in-depth information and can go beyond visual preferences, e.g., aesthetic experiences, feelings and values $[25,27]$. However, it may be difficult to compare aesthetic values of different lakes.

Nevertheless, our findings can be useful to assess cultural ecosystem services of mountain lakes, i.e., non-material benefits originating from human interactions with ecosystems [35] and to develop management strategies in the light of increasing demand for nature-based experiences [23]. This is particularly important for lakes that are reachable by car such as Pragser Wildsee, which indeed has very high visitation rates compared to other lakes [1]. Here, the visual water quality could be affected by aquatic recreation or recreational activities at the lake shore contributing to increasing levels of eutrophication [19-21]. Moreover, introducing fish in naturally fishless lakes for recreational angling purposes has not only huge consequences on the lake ecosystem [36], but water quality may also be affected due to fish feeding [19]. High visitation rates may also have negative impacts on the surrounding flora and fauna by increased levels of pollution, trampling and disturbance of wildlife, which can counteract conservation efforts $[37,38]$ and are conflicting with the interests of non-recreational users such as forest managers, hunters, and pastoralists [39]. Moreover, perceived crowding affects the quality of nature-based experiences and often leads to conflicts between different visitors or user groups [40-42].

While lakes of high aesthetic value are often used for promoting tourism; the example of Pragser Wildsee demonstrates that this may cause undesired socio-ecological outcomes. This lake, recognised as one of the most beautiful lakes in the European Alps by different newspaper and magazines, has become famous through the Italian television series "Un passo dal cielo" (One step from heaven). Moreover, the distribution of photographs of the lake through social media by visitors attracts further visitors and has been identified as an important push factor for overtourism, causing a decline in the tourist destination and conflicts with the local population [43,44]. Due to such conflicts, mostly related to traffic congestions, local authorities have taken initial measures to restrict the accessibility by car and to reduce the number of visitors to limit negative effects on the environment and socio-economic context [45]. Although social media data may support the identification of lakes that need particular attention for management, these data may only partly be used as proxy for the aesthetic value of lakes, as visitation rates rather depend on spatial and temporal accessibility, population density and tourism intensity, as well as the presence of (cultural) attractions $[1,46,47]$.

\section{Conclusions}

Our results confirm the preference for visually clear and clean water as well as natural environments. Our findings also emphasize the importance of adopting a holistic perspective for assessing aesthetic values of mountain lakes, as they favour visual aesthetic experiences over water-based activities due to their specific biophysical characteristics and remoteness. Future studies with regard to nature-based experiences or ecosystem services should therefore widen the focus from the lake water to the entire landscape in proximity to the lakes, which could support the assessment of associated societal values and benefits for subjective well-being.

For decision-making, it is necessary to reconcile various interests of using mountain lakes. Our findings suggest that it is crucial to preserve the high water quality and to avoid modifications of the lake and the surroundings to maintain high aesthetic values. Therefore, constructions for water regulation (as for hydropower generation) or any other modification of the natural settings of mountain lakes should be evaluated in terms of impacts on 
uses, preferences and aesthetic values. This means that recreational angling should also be regulated, in particular fish introduction and feeding, which affects water clarity in addition to altering the entire ecosystem. Moreover, it may be necessary to rethink tourism development or to invest into innovative ways of visitor guidance, awareness raising and environmental education, while regulating the accessibility to sensitive environments.

Author Contributions: Conceptualization, U.S.; formal analysis, U.S.; data curation, U.S.; writingoriginal draft preparation, U.S.; writing — review and editing, R.S. and U.T. All authors have read and agreed to the published version of the manuscript.

Funding: This research was funded by the Austrian Federal Ministry of Education, Science and Research, project CLAIMES (CLimate response of AlpIne lakes: resistance variability and Management consequences for Ecosystem Services) under the Earth System Sciences research programme, which is an initiative of the Austrian Academy of Sciences.

Institutional Review Board Statement: Ethical approval was not required for this study, as the survey was anonymous and no personal information was collected that could be used to identify an individual.

Informed Consent Statement: Informed consent was obtained from all subjects involved in the study.

Data Availability Statement: The data presented in this study are available in the Appendix A.

Acknowledgments: We acknowledge the contribution by Alexander Kiessling in elaborating and distributing the questionnaire. We also thank all respondents for their participation and valuable answers. Moreover, we thank Rainer Kurmayer and team (Department of Linmology, University of Innsbruck, Austria) for providing the limnological data of the study lakes. The authors thank the Department of Innovation, Research, University and Museums of the Autonomous Province of Bozen/Bolzano for covering the Open Access publication costs.

Conflicts of Interest: The authors declare no conflict of interest.

\section{Appendix A}

Table A1. Terms mentioned by the respondents to characterize a mountain lake. Terms were aggregated to groups and related to four major categories. Frequencies are indicted in brackets and sorted in descending order.

\begin{tabular}{|c|c|c|}
\hline Category & Group & Term \\
\hline Water (664) & $\begin{array}{l}\text { Visual water quality (237) } \\
\text { Water temperature }(148) \\
\text { Water colour }(129) \\
\text { Water quality (88) } \\
\text { Water surface (62) }\end{array}$ & $\begin{array}{c}\text { clear (219), crystal (8), transparent (8), turbid (2) } \\
\text { cold (108), cool (16), fresh (14), temperature (8), frozen (1), glacier water (1) } \\
\text { colour (83), blue (22), blue-green (8), turquoise (6), green (5), dark (2), opalescent (2), emerald (1) } \\
\text { clean (67), pure (14), low nutrients (4), drinking water quality (2), water quality (1) } \\
\text { reflection (34), calm (23), shine (3), surface (2) }\end{array}$ \\
\hline Lake (357) & $\begin{array}{l}\text { Lake shape (124) } \\
\text { Lake shore (118) } \\
\text { Ecosystem quality (60) } \\
\text { Flora and fauna (55) }\end{array}$ & $\begin{array}{l}\text { small (34), size (24), shape (16), profound (14), irregular (9), round (5), formation (4), shallow (4), tributaries } \\
\text { (4), glacial formation (2), lakebed (2), oval (2), water level changes (2), no tributaries (1), sediments (1) } \\
\text { natural (90), rocky (16), vegetation (4), shore (3), mud (1), shallow (1), slope (1), steep (1), trees (1) } \\
\text { pristine (36), nature (22), ecological balance (2) } \\
\text { wildlife (18), few fish / fishless (11), fish (10), flora and fauna (6), biodiversity (4), no water plants (2), few } \\
\text { water plants (1), flora (1), water plants (1), without reed (1) }\end{array}$ \\
\hline Experience (236) & $\begin{array}{l}\text { Sentiment (111) } \\
\text { Atmosphere (107) } \\
\text { Accessibility (18) }\end{array}$ & $\begin{array}{l}\text { beautiful (32), refreshing (13), break (4), life (4), relaxing (4), fascinating (3), freedom (3), worth protecting } \\
\text { (3), breathing (2), few people (2), romantic (2), serenity (2), too cold for swimming (2), uniqueness (2), } \\
\text { vulnerable (2), admiration (1), adventure (1), aesthetic element (1), breath-taking (1), calming (1), crowded } \\
(1) \text {, dramatic (1), extraordinary (1), gurgle (1), happiness (1), harmonious (1), history of earth (1), } \\
\text { impressive (1), intensive (1), inviting (1), joy (1), lovely (1), magic (1), persistence (1), picturesque (1), } \\
\text { positive energy (1), rough beauty (1), spectacular (1), splendid (1), sweet (1), swimming (1), too cold for } \\
\text { bathing (1), tourism (1), water sound (1), wet (1), wonder (1) } \\
\text { tranquillity (51), silence (14), idyllic (10), loneliness (10), peaceful (10), wilderness (5), atmosphere (2), } \\
\text { special (2), wideness (2), pleasantness (1) } \\
\text { accessible (5), few tourism (2), hiking (2), no fishing (2), no tourist attractions (2), bathing allowed (1), no } \\
\text { bathing (1), no bathing establishment (1), no swimming (1), some hiking trails (1) }\end{array}$ \\
\hline Location (178) & & $\begin{array}{c}\text { mountains (30), vegetation (16), big whole (15), naturalness (15), surroundings (14), location (13), alpine } \\
\text { vegetation (11), high-elevated (10), rocks (10), remoteness (9), landscape (8), scenery (4), trees (4), contrast } \\
\text { to landscape (3), forest (3), near glacier/snow (3), sparse vegetation (3), contrasting (1), few trees (1), gem } \\
\text { between rocks (1), no forest (1), no high vegetation (1), no settlements (1), no traffic (1) }\end{array}$ \\
\hline
\end{tabular}


Table A2. Mean scores for each picture and socio-cultural groups. Statistically significant differences are indicated by ${ }^{*} p<0.05,{ }^{* *} p<0.01,{ }^{* * *} p<0.001$ (Chi-squared test).

\begin{tabular}{|c|c|c|c|c|c|c|c|c|c|c|c|c|c|}
\hline \multirow{2}{*}{ Picture } & \multirow{2}{*}{ Total } & \multicolumn{2}{|c|}{ Gender } & \multicolumn{2}{|c|}{ Age } & \multicolumn{2}{|c|}{ Cultural Background } & \multicolumn{2}{|c|}{ Relation to Alps } & \multicolumn{2}{|c|}{ Nature Connectedness } & \multicolumn{2}{|c|}{ Lake Affinity } \\
\hline & & Female & Male & $<40$ & $40+$ & German & Italian & Residents & Tourists & Low & High & Low & High \\
\hline & $N=526$ & $N=320$ & $N=201$ & $N=253$ & $N=256$ & $N=294$ & $N=210$ & $N=199$ & $N=229$ & $N=187$ & $N=335$ & $N=255$ & $N=268$ \\
\hline 1a & 0.835 & 0.841 & 0.826 & 0.870 * & $0.805 *$ & 0.840 & 0.829 & 0.834 & 0.834 & 0.861 & 0.821 & 0.839 & 0.828 \\
\hline $1 \mathrm{~b}$ & 0.165 & 0.159 & 0.174 & 0.130 * & $0.195^{*}$ & 0.160 & 0.171 & 0.166 & 0.166 & 0.139 & 0.179 & 0.161 & 0.172 \\
\hline $2 a$ & 0.544 & 0.547 & 0.542 & 0.565 & 0.523 & 0.517 & 0.562 & 0.523 & 0.555 & 0.561 & 0.540 & 0.537 & 0.552 \\
\hline $2 \mathrm{~b}$ & 0.080 & 0.075 & 0.085 & 0.075 & 0.078 & 0.099 & 0.062 & 0.075 & 0.074 & 0.075 & 0.081 & 0.102 & 0.056 \\
\hline $2 \mathrm{c}$ & 0.376 & 0.378 & 0.373 & 0.360 & 0.398 & 0.384 & 0.376 & 0.402 & 0.371 & 0.364 & 0.379 & 0.361 & 0.392 \\
\hline $3 a$ & 0.462 & 0.453 & 0.478 & 0.466 & 0.461 & 0.442 & 0.471 & 0.437 & 0.476 & 0.519 & 0.430 & 0.467 & 0.455 \\
\hline $3 \mathrm{~b}$ & 0.414 & 0.428 & 0.393 & 0.399 & 0.434 & 0.459 * & 0.371 * & 0.452 & 0.367 & 0.385 & 0.430 & 0.427 & 0.403 \\
\hline $3 c$ & 0.027 & 0.028 & 0.025 & 0.028 & 0.023 & 0.014 * & 0.043 * & 0.035 & 0.031 & 0.021 & 0.030 & $0.008 * *$ & $0.045^{* *}$ \\
\hline $3 \mathrm{~d}$ & 0.097 & 0.091 & 0.104 & 0.107 & 0.082 & 0.085 & 0.114 & 0.075 & 0.127 & 0.075 & 0.110 & 0.098 & 0.097 \\
\hline $4 a$ & 0.078 & 0.078 & 0.075 & 0.040 ** & $0.109^{* *}$ & 0.048 ** & $0.129^{* *}$ & 0.070 & 0.074 & 0.075 & 0.081 & 0.067 & 0.090 \\
\hline $4 \mathrm{~b}$ & 0.460 & 0.494 * & $0.403^{*}$ & 0.510 & 0.414 & $0.493 *$ & 0.395 * & 0.412 & 0.498 & 0.481 & 0.448 & 0.514 * & 0.407 * \\
\hline $4 \mathrm{c}$ & 0.057 & 0.053 & 0.060 & 0.032 ** & $0.086^{* *}$ & 0.051 & 0.067 & 0.055 & 0.061 & 0.070 & 0.048 & 0.067 & 0.049 \\
\hline $4 \mathrm{~d}$ & 0.405 & 0.375 * & $0.463^{*}$ & 0.419 & 0.391 & 0.408 & 0.410 & 0.462 * & $0.367^{*}$ * & 0.374 & 0.424 & 0.353 * & 0.455 * \\
\hline $5 a$ & 0.700 & 0.731 & 0.652 & 0.763 ** & $0.637^{* *}$ & 0.731 * & 0.648 * & 0.714 & 0.686 & 0.663 & 0.722 & 0.682 & 0.720 \\
\hline $5 b$ & 0.162 & 0.147 & 0.184 & $0.091 * * *$ & $0.234^{* * *}$ & 0.139 & 0.200 & 0.141 & 0.188 & 0.187 & 0.146 & 0.169 & 0.153 \\
\hline $5 c$ & 0.059 & 0.066 & 0.050 & 0.059 & 0.059 & 0.044 & 0.076 & 0.050 & 0.057 & 0.070 & 0.054 & 0.063 & 0.056 \\
\hline $5 \mathrm{~d}$ & 0.080 & $0.056^{*}$ & 0.114 * & 0.087 & 0.070 & 0.085 & 0.076 & 0.095 & 0.070 & 0.080 & 0.078 & 0.086 & 0.071 \\
\hline $6 a$ & 0.099 & 0.091 & 0.114 & 0.087 & 0.109 & 0.116 & 0.081 & $0.156^{* * *}$ & $0.057 * * *$ & 0.070 & 0.116 & $0.067^{*}$ & 0.131 * \\
\hline $6 \mathrm{~b}$ & 0.196 & 0.191 & 0.204 & 0.221 & 0.176 & 0.184 & 0.210 & 0.241 & 0.170 & 0.155 & 0.218 & $0.118^{* * *}$ & $0.272 * * *$ \\
\hline $6 c$ & 0.236 & 0.238 & 0.234 & $0.198^{*}$ & $0.277^{*}$ & 0.252 & 0.238 & 0.226 & 0.249 & 0.262 & 0.224 & 0.255 & 0.220 \\
\hline $6 \mathrm{~d}$ & 0.470 & 0.481 & 0.448 & 0.494 & 0.438 & 0.449 & 0.471 & $0.377^{* *}$ & 0.524 ** & 0.513 & 0.442 & $0.561^{* * * *}$ & $0.377^{* * *}$ \\
\hline
\end{tabular}

\section{References}

1. Schirpke, U.; Tasser, E.; Ebner, M.; Tappeiner, U. What can geotagged photographs tell us on cultural ecosystem services of lakes? Ecosyst. Serv. 2021. under review.

2. Angradi, T.R.; Ringold, P.L.; Hall, K. Water clarity measures as indicators of recreational benefits provided by U.S. lakes: Swimming and aesthetics. Ecol. Indic. 2018, 93, 1005-1019. [CrossRef]

3. Tallar, R.Y.; Suen, J.P. Measuring the aesthetic value of multifunctional lakes using an enhanced visual quality method. Water 2017, 9, 233. [CrossRef]

4. Vesterinen, J.; Pouta, E.; Huhtala, A.; Neuvonen, M. Impacts of changes in water quality on recreation behavior and benefits in Finland. J. Environ. Manag. 2010, 91, 984-994. [CrossRef]

5. West, A.O.; Nolan, J.M.; Scott, J.T. Optical water quality and human perceptions of rivers: An ethnohydrology study. Ecosyst. Health Sustain. 2016, 2, e01230. [CrossRef]

6. Gall, M.P.; Davies-Colley, R.J.; Merrilees, R.A. Exceptional visual clarity and optical purity in a sub-alpine lake. Limnol. Oceanogr. 2013, 58, 443-451. [CrossRef]

7. Suplee, M.W.; Watson, V.; Teply, M.; McKee, H. How green is too green? Public opinion of what constitutes undesirable algae levels in streams. J. Am. Water Resour. Assoc. 2009, 45, 123-140. [CrossRef]

8. Lee, L.-H. Appearance's Aesthetic Appreciation to Inform Water Quality Management of Waterscapes. J. Water Resour. Prot. 2017, 09, 1645-1659. [CrossRef]

9. Palmer, S.E.; Schloss, K.B. An ecological valence theory of human color preference. Proc. Natl. Acad. Sci. USA 2010, 107, 8877-8882. [CrossRef]

10. Cottet, M.; Piégay, H.; Bornette, G. Does human perception of wetland aesthetics and healthiness relate to ecological functioning? J. Environ. Manage. 2013, 128, 1012-1022. [CrossRef]

11. Keeler, B.L.; Wood, S.A.; Polasky, S.; Kling, C.; Filstrup, C.T.; Downing, J.A. Recreational demand for clean water: Evidence from geotagged photographs by visitors to lakes. Front. Ecol. Environ. 2015, 13, 76-81. [CrossRef]

12. Hunt, L.M. Recreational fishing site choice models: Insights and future opportunities. Hum. Dimens. Wildl. 2005, 10, 153-172. [CrossRef]

13. Cai, X.; Boromisza, Z. Public perceptions and aesthetic preferences of lakeshore landscape: The example of Lake Velence (Hungary). Landsc. Environ. 2020, 14, 31-42. [CrossRef]

14. Lin, L.; Homma, R.; Iki, K. Preferences for a lake landscape: Effects of building height and lake width. Environ. Impact Assess. Rev. 2018, 70, 22-33. [CrossRef]

15. Wu, J.; Ling, C.; Li, X. Study on the Accessibility and Recreational Development Potential of Lakeside Areas Based on Bike-Sharing Big Data Taking Wuhan City as an Example. Sustainability 2020, 12, 160. [CrossRef]

16. Williamson, C.E.; Saros, J.E.; Vincent, W.F.; Smol, J.P. Lakes and reservoirs as sentinels, integrators, and regulators of climate change. Limnol. Oceanogr. 2009, 54, 2273-2282. [CrossRef]

17. Schmeller, D.S.; Loyau, A.; Bao, K.; Brack, W.; Chatzinotas, A.; De Vleeschouwer, F.; Friesen, J.; Gandois, L.; Hansson, S.V.; Haver, M.; et al. People, pollution and pathogens-Global change impacts in mountain freshwater ecosystems. Sci. Total Environ. 2018, 622-623, 756-763. [CrossRef]

18. Moser, K.A.; Baron, J.S.; Brahney, J.; Oleksy, I.A.; Saros, J.E.; Hundey, E.J.; Sadro, S.A.; Kopáček, J.; Sommaruga, R.; Kainz, M.J.; et al. Mountain lakes: Eyes on global environmental change. Glob. Planet. Chang. 2019, 178, 77-95. [CrossRef]

19. Weckström, K.; Weckström, J.; Huber, K.; Kamenik, C.; Schmidt, R.; Salvenmoser, W.; Rieradevall, M.; Weisse, T.; Psenner, R.; Kurmayer, R. Impacts of Climate Warming on Alpine Lake Biota over the Past Decade. Arct. Antarct. Alp. Res. 2016, 48, 361-376. [CrossRef] 
20. Dokulil, M.T. Environmental Impacts of Tourism on Lakes. In BT-Eutrophication: Causes, Consequences and Control; Ansari, A.A., Gill, S.S., Eds.; Springer: Dordrecht, The Netherlands, 2014; Volume 2, pp. 81-88, ISBN 978-94-007-7814-6.

21. Senetra, A.; Dynowski, P.; Cieślak, I.; Źróbek-Sokolnik, A. An evaluation of the impact of hiking tourism on the ecological status of alpine lakes-a case study of the valley of dolina pieciu stawow polskich in the tatra mountains. Sustainability 2020, 12, 2963. [CrossRef]

22. Völker, S.; Kistemann, T. The impact of blue space on human health and well-being-Salutogenetic health effects of inland surface waters: A review. Int. J. Hyg. Environ. Health 2011, 214, 449-460. [CrossRef]

23. Buckley, R.; Gretzel, U.; Scott, D.; Weaver, D.; Becken, S. Tourism megatrends. Tour. Recreat. Res. 2015, 40, 59-70. [CrossRef]

24. Couper, M.P.; Tourangeau, R.; Conrad, F.G.; Crawford, S.D. What They See Is What We Get: Response Options for Web Surveys. Soc. Sci. Comput. Rev. 2004, 22, 111-127. [CrossRef]

25. Wartmann, F.M.; Purves, R.S. Investigating sense of place as a cultural ecosystem service in different landscapes through the lens of language. Landsc. Urban Plan. 2018, 175, 169-183. [CrossRef]

26. ASTAT Zeitreihe zum Tourismus und Gemeindetabellen-1950-2019. Available online: https://astat.provinz.bz.it/de/aktuellespublikationen-info.asp?news_action=300\&news_image_id=1078375 (accessed on 23 February 2021).

27. Bieling, C.; Plieninger, T.; Pirker, H.; Vogl, C.R. Linkages between landscapes and human well-being: An empirical exploration with short interviews. Ecol. Econ. 2014, 105, 19-30. [CrossRef]

28. Antrop, M.; Van Eetvelde, V. Holistic aspects of suburban landscapes: Visual image interpretation and landscape metrics. Landsc. Urban Plan. 2000, 50, 43-58. [CrossRef]

29. Orians, G.H. Habitat selection: General theory and applications to human behavior. In The Evolution of Human Social Behavior; Lockard, S.J., Ed.; Elsevier: Chigago, IL, USA, 1980; pp. 49-66.

30. Schirpke, U.; Timmermann, F.; Tappeiner, U.; Tasser, E. Cultural ecosystem services of mountain regions: Modelling the aesthetic value. Ecol. Indic. 2016, 69, 78-90. [CrossRef] [PubMed]

31. Tveit, M.S. Indicators of visual scale as predictors of landscape preference; a comparison between groups. J. Environ. Manag. 2009, 90, 2882-2888. [CrossRef]

32. Ode, Å.; Fry, G.; Tveit, M.S.; Messager, P.; Miller, D. Indicators of perceived naturalness as drivers of landscape preference. J. Environ. Manag. 2009, 90, 375-383. [CrossRef] [PubMed]

33. European Union. Guidance on the Requirements for Hydropower in Relation to EU Nature Legislation; European Union: Luxembourg, 2018.

34. Lavdas, A.A.; Schirpke, U. Aesthetic preference is related to organized complexity. PLoS ONE 2020, 15, e0235257. [CrossRef]

35. Fish, R.; Church, A.; Winter, M. Conceptualising cultural ecosystem services: A novel framework for research and critical engagement. Ecosyst. Serv. 2016, 21, 208-217. [CrossRef]

36. Miró, A.; O’Brien, D.; Tomàs, J.; Buchaca, T.; Sabás, I.; Osorio, V.; Lucati, F.; Pou-Rovira, Q.; Ventura, M. Rapid amphibian community recovery following removal of non-native fish from high mountain lakes. Biol. Conserv. 2020, 251, 108783. [CrossRef]

37. Barros, A.; Pickering, C.M. How Networks of Informal Trails Cause Landscape Level Damage to Vegetation. Environ. Manag. 2017, 60, 57-68. [CrossRef] [PubMed]

38. Marion, J.L.; Leung, Y.-F.; Eagleston, H.; Burroughs, K. A Review and Synthesis of Recreation Ecology Research Findings on Visitor Impacts to Wilderness and Protected Natural Areas. J. For. 2016, 114, 352-362. [CrossRef]

39. Wilkes-Allemann, J.; Pütz, M.; Hirschi, C.; Fischer, C. Conflict situations and response strategies in urban forests in Switzerland. Scand. J. For. Res. 2015, 30, 204-216. [CrossRef]

40. Scolozzi, R.; Schirpke, U.; Detassis, C.; Abdullah, S.; Gretter, A. Mapping Alpine Landscape Values and Related Threats as Perceived by Tourists. Landsc. Res. 2015, 40, 451-465. [CrossRef]

41. Schirpke, U.; Scolozzi, R.; Dean, G.; Haller, A.; Jäger, H.; Kister, J.; Kovács, B.; Sarmiento, F.O.; Sattler, B.; Schleyer, C. Cultural ecosystem services in mountain regions: Conceptualising conflicts among users and limitations of use. Ecosyst. Serv. 2020, 46, 101210. [CrossRef]

42. Confer, J.J.; Thapa, B.; Mendelsohn, J.L. Exploring a typology of recreation conflict in outdoor environments. World Leis. J. 2005, 47, 12-23. [CrossRef]

43. Gatterer, P.J. Instagram the, Chameleon'-The Biggest Influencer of Overtourism in Rural Destinations. Master's Thesis, Modul University Vienna, Vienna, Austria, 2020. Available online: https://www.modul.ac.at/uploads/files/Theses/Master/MBA_20 20/1602010_Peter_Gatterer_thesis_no_sig.pdf (accessed on 20 April 2021).

44. Cagnina, M.R.; Cicero, L.; Osti, L.; Pizzuto, L. Uncontrolled positive promotion and tourists' satisfaction. In Proceedings of the XVI Conference Società Italiana Marketing, Piacenza, Italy, 24-25 October 2019; Volume 4, pp. $24-25$.

45. Unterkofler, F. Nachhaltige Tourismusmobilität in Südtirol-Implementierung von Mobility as a Service für Touristen. Diploma Thesis, TU Wien, Vienna, Austria, 2019. Available online: https://repositum.tuwien.at/handle/20.500.12708/1459 (accessed on 20 April 2021).

46. Tieskens, K.F.; Van Zanten, B.T.; Schulp, C.J.E.; Verburg, P.H. Aesthetic appreciation of the cultural landscape through social media: An analysis of revealed preference in the Dutch river landscape. Landsc. Urban Plan. 2018, 177, 128-137. [CrossRef]

47. Sinclair, M.; Ghermandi, A.; Moses, S.A.; Joseph, S. Recreation and environmental quality of tropical wetlands: A social media based spatial analysis. Tour. Manag. 2019, 71, 179-186. [CrossRef] 